\title{
Analisis Hasil Belajar Matematika Peserta Didik Ditinjau dari Self Confidence
}

\author{
Nida Savira Maulidya ${ }^{1}$, Esti Ambar Nugraheni ${ }^{2}$ \\ ${ }^{1,2}$ Prodi Pendidikan Matematika, Fakultas Keguruan dan Ilmu Pendidikan, Universitas Muhammadiyah Prof. Dr. HAMKA, \\ Jl. Tanah Merdeka No 20, Jakarta Timur, Indonesia \\ nidasaviramldya@gmail.com
}

\begin{abstract}
Student learning outcomes are one of the benchmarks of success in the world of education to measure the ability, understanding, and mastery of materials after going through the learning process. This study aims to find out and analyze the results of mathematics learning outcomes reviewed from self-confidence. The method used is descriptive method with qualitative approach. Sampling technique used by giving tests with a 5 essay questions and selfconfidence questionnaire with 24 statements and interviews. The subjects of the study were grade VII students with a total of 6 people. The results showed that there is a relationship between self-confidence and mathematics learning outcomes of students. Based on achievement of percentage of mathematics learning outcomes according to selfconfidence level, if self-confidence of student is high then mathematics learning outcomes are also high. Overall, the achievement of mathematics learning results obtained by students was $73.83 \%$.
\end{abstract}

Keywords: Analysis, Mathematics Learning Outcomes, Self Confidence

\begin{abstract}
Abstrak
Hasil belajar peserta didik merupakan salah satu tolok ukur keberhasilan dalam dunia pendidikan untuk mengukur kemampuan, pemahaman, dan penguasaan materi setelah melalui proses pembelajaran. Penelitian ini bertujuan untuk mengetahui dan menganalisis hasil belajar matematika peserta didik ditinjau dari self-confidence. Metode yang digunakan yaitu metode deskriptif dengan pendekatan kualitatif. Teknik pengumpulan yang dipakai dengan pemberian tes dengan jumlah 5 soal uraian dan pemberian kuesioner self-confidence yang terdiri dari 24 pernyataan serta wawancara. Subjek penelitian ini merupakan peserta didik kelas VII dengan jumlah 6 orang. Hasil penelitian ini menunjukkan bahwa terdapat hubungan antara self-confidence dengan hasil belajar matematika peserta didik. Berdasarkan dari persentase pencapaian hasil belajar matematika menurut tingkat self-confidence, jika self-confidence peserta didik tinggi maka hasil belajar matematika peserta didik juga tinggi. Secara keseluruhan, perolehan hasil belajar matematika peserta didik sebesar 73,83\%.
\end{abstract}

Kata kunci: Analisis Hasil Belajar, Matematika, Kepercayaan Diri

Copyright (c) 2021 Nida Savira Maulidya, Esti Ambar Nugraheni

$\triangle$ Corresponding author: Esti Ambar Nugraheni

Email Address: esti0507@uhamka.ac.id (Jl. Tanah Merdeka No 20, Jakarta Timur, Indonesia)

Received 17 July 2021, Accepted 03 August 2021, Published 09 August 2021

\section{PENDAHULUAN}

Pembelajaran merupakan hal penting dalam dunia pendidikan, untuk membantu mengoptimalkan kemampuan peserta didik baik kognitif, afektif, dan psikomotorik. Dalam tujuan pendidikan nasional, mencakup berbagai macam disiplin ilmu, salah satunya merupakan matematika (Ferdianto \& Yesino, 2019). Matematika merupakan ratu ilmu, memiliki peranan penting dalam dunia pendidikan, karena sebagai ilmu dasar yang melatih kemampuan berhitung dan berpikir kritis peserta didik. Sehingga tidak jarang tolok ukur kecerdasan seseorang dilihat dari pelajaran matematika.

Pembelajaran matematika menjadi salah satu pengetahuan dasar terpenting karena memiliki hubungan yang sangat erat dengan kehidupan sehari-hari yang bertujuan untuk mengasah pemikiran dari permasalahan yang rumit. Namun kenyataannya peserta didik di sekolah lebih dominan tidak suka dengan mata pelajaran matematika karena dianggap sebagai mata pelajaran yang sukar dan memiliki banyak rumus serta perhitungan. Sehingga membuat peserta didik tidak memiliki minat dan motivasi untuk belajar 
matematika yang mengakibatkan hasil belajar matematika peserta didik di sekolah cukup rendah (Salamah \& Amelia, 2020)

Hasil belajar peserta didik menjadi salah satu tolok ukur keberhasilan dalam dunia pendidikan saat pembelajaran (Saihu, 2020), meliputi perubahan tingkah laku yang mencakup ranah kognitif, afektif, dan psikomotorik (Yukentin et al., 2018). Hasil belajar matematika peserta didik yang rendah dapat diasumsikan bahwa kurangnya penguasaan terhadap materi (Sari et al., 2019), karena ketepatan dari hasil belajar matematika peserta didik erat kaitannya terhadap ranah kognitif, kegiatan yang menyangkut aktivitas otak dan berorientasi pada kemampuan berpikir peserta didik. Berdasarkan taksonomi bloom, ranah kognitif terdiri dari pengetahuan (knowledge), pemahaman (comprehension), penerapan (application), analisis (analysis), sintesis (syntesis), penilaian (evaluation) (Oktaviana \& Prihatin, 2018).

Hasil belajar kognitif matematika peserta didik berupa hasil yang telah dicapai melalui suatu tes untuk mengukur kemampuan, pemahaman, dan penguasaan materi yang dimiliki setelah mengikuti proses pembelajaran matematika dalam jangka waktu tertentu (Nuriati et al., 2021). Selain kurangnya penguasaan terhadap materi, pencapaian hasil belajar peserta didik dapat dipengaruhi juga oleh beberapa faktor lain yaitu, faktor internal dan faktor eksternal.

Faktor internal adalah faktor yang berhubungan dengan diri sendiri, berasal dari dalam diri, meliputi kemampuan verbal dan non-verbal, minat belajar, motivasi belajar, aspek afektif, dan lain-lain. Sedangkan faktor eksternal adalah faktor yang berhubungan dengan lingkungan, berasal dari luar diri, meliputi sarana dan prasarana sekolah, guru, media pembelajaran, dan lain-lain. Meskipun kedua faktor tersebut menjadi penentu, tetapi aspek afektif lebih mendominasi. Senada dengan (Sari et al., 2019) bahwa aspek afektif lebih mendominasi dalam pencapaian hasil belajar matematika peserta didik. Dalam dunia pendidikan, aspek afektif berhubungan dengan sikap dan motivasi seseorang (Hildingsson et al., 2019). Salah satu aspek afektif yang mempengaruhi yaitu self-confidence (kepercayaan diri).

Self confidence merupakan percaya pada kemampuan pribadi (Masruroh et al., 2019), yang dapat mendorong semangat dan kecerdasan peserta didik saat mengikuti pembelajaran matematika (Ramdan et al., 2018) dan memberikan pengaruh pada hasil belajarnya, karena dengan kepercayaan diri yang dimiliki, peserta didik akan lebih mengoptimalkan kemampuannya. Senada dengan (Novtiar \& Aripin, 2017) yang menyatakan bahwa kepercayaan diri membantu peserta didik dalam memecahkan masalah agar dapat mengoptimalkan kemampuan yang dimiliki.

Dalam dunia pendidikan, kepercayaan diri berkaitan dengan karakteristik pribadi, motivasi, dan sikap seseorang (Hildingsson et al., 2019). Kurangnya kepercayaan diri membuat peserta didik merasa tidak mampu menyelesaikan suatu masalah, sehingga menjadi salah satu penyebab terjadinya kesulitan dalam proses pembelajaran (Nuraeni et al., 2018). Kepercayaan diri dapat membantu peserta didik dalam menumbuhkan bakat, minat dan potensi dalam diri agar mencapai prestasi belajar (Nurul et al., 2019), serta memacu peserta didik untuk eksplorasi dan menemukan konsep dari suatu materi (Ramdan et al., 2018).

Menurut hasil penelitian yang dilakukan oleh (Masruroh et al., 2019), peserta didik dengan tingkat self-confidence tinggi akan memperoleh hasil belajar yang maksimal. Hal tersebut juga dibuktikan oleh 
(Nilasari et al., 2020) yang mengatakan jika peserta didik yang memiliki tingkat kepecayaan diri yang tinggi cenderung memiliki hasil belajar yang juga tinggi. Selain itu, temuan (Trisnawati et al., 2018) menyatakan bahwa rasa ingin tahu peserta didik semakin terdorong saat mereka memiliki tingkat self-confidence tinggi, begitupun sebaliknya.

Kurangnya kepercayaan diri akan menyebabkan peserta didik tidak dapat menyelesaikan soal akibat tidak memahami konsepnya, sehingga mereka sekadar menerka-nerka solusi dari permasalahan yang diberikan (Salamah \& Amelia, 2020). Sehingga akan berakibat pada prestasi hasil belajar peserta didik yang kurang maksimal. Berdasarkan hal tersebut, terlihat bahwa self-confidence (kepercayaan diri) penting untuk dimiliki peserta didik agar mereka dapat mengoptimalkan kemampuan yang dimiliki, mendorong semangat serta kecerdasan peserta didik sehingga pencapaian hasil belajar peserta didik lebih maksimal. Dalam penelitian ini hasil belajar matematika peserta didik yang dimaksud adalah di fokuskan pada ranah kognitif setelah peserta didik mengikuti materi pembelajaran matematika yang di tinjau berdasarkan kategori tingkat self-confidence yang dimiliki, dengan menyesuaikan pada materi yang telah dipelajari oleh peserta didik di sekolahnya.

Berdasarkan uraian di atas, terlihat bahwa aspek afektif yaitu self-confidence merupakan salah satu faktor yang dapat memberikan pengaruh baik terhadap pencapaian hasil belajar matematika peserta didik. Oleh sebab itu, peneliti bertujuan untuk menganalisis dan mendeskripsikan hasil belajar matematika peserta didik ditinjau dari self-confidence yang dikategorikan dengan tingkatan self-confidence tinggi, sedang, rendah.

\section{METODE}

Penelitian ini merupakan penelitian kualitatif dengan menggunakan metode deskriptif. Menurut Prof. Dr. Sugiyono (2016), penelitian kualitatif merupakan metode penelitian berlandaskan pada postpositivisme untuk meneliti objek alamiah. Penelitian ini menggunakan instrumen tes dan non-tes. Intrumen tes terdiri dari 5 soal uraian berdasarkan indikator hasil belajar.

Sedangkan instrumen non-tes yang digunakan adalah angket self-confidence berdasarkan 4 indikator dengan 4 pilihan respon, yaitu Sangat Setuju (SS), Setuju (S), (TS) Tidak Setuju, dan Sangat Tidak Setuju (STS). Dilanjutkan dengan wawancara kepada 6 orang peserta didik berdasarkan tingkat selfconfidence yang dimiliki. Indikator self-confidence menurut Nurojab \& Sari (2019), yaitu: 1) Percaya kepada kemampuan pribadi, 2) Mengambil keputusan secara mandiri, 3) Memiliki konsep diri yang positif, 4) Berani mengungkapkan pendapat atau ide.

Teknik analisis data pada instrumen non-tes di analisis menggunakan skala Likert. Pada pernyataan positif skor yang digunakan $4=\mathrm{SS}, 3=\mathrm{S}$, TS $=$ TS, $1=$ STS, begitupun sebaliknya untuk pernyataan negatif. Sedangkan instrumen tes dilakukan dengan cara menilai pencapaian rata-rata nilai peserta didik dengan bobot yang telah ditentukan kemudian di analisis secara deskriptif berdasarkan tingkat selfconfidence peserta didik. Hasil wawancara di analisis secara deskriptif untuk mengetahui lebih dalam mengenai hambatan yang dialami oleh peserta didik. 
Pada penelitian ini, penulis mengelompokkan peserta didik berdasarkan tingkat self-confidence dengan menggunakan kriteria pengelompokkan self-confidence seperti pada tabel 1 .

Tabel 1. Kriteria Pengelompokkan Self Confidence

\begin{tabular}{|c|c|}
\hline Kriteria Self Confidence & Tingkat Self Confidence \\
\hline $\mathrm{x} \geq(\overline{\mathrm{x}}+\mathrm{SD})$ & Tinggi \\
\hline$(\overline{\mathrm{x}}-\mathrm{SD})<\mathrm{x}<(\overline{\mathrm{x}}+\mathrm{SD})$ & Sedang \\
\hline $\mathrm{x} \leq(\overline{\mathrm{x}}-\mathrm{SD})$ & Rendah \\
\hline
\end{tabular}

Sumber: (Ulfa et al., 2019)

Berikut contoh instrumen yang digunakan selama penelitian sebagai berikut:

\begin{tabular}{|c|l|c|c|c|c|}
\hline \multirow{2}{*}{ No } & \multicolumn{1}{|c|}{ Pernyataan } & \multicolumn{3}{c|}{ Respons } \\
\cline { 3 - 6 } & SS & S & TS & STS \\
\hline A1 & $\begin{array}{l}\text { Saya yakin dapat berbicara ketika harus menjelaskan } \\
\text { materi pelajaran matematika di depan kelas. }\end{array}$ & & & & \\
\hline A2 & $\begin{array}{l}\text { Saya dapat menyelesaikan tugas matematika tanpa } \\
\text { bantuan orang lain. }\end{array}$ & & & & \\
\hline A3 & $\begin{array}{l}\text { Saya yakin akan berhasil dan mendapatkan nilai yang } \\
\text { baik dalam pelajaran matematika. }\end{array}$ & & & & \\
\hline A4 & $\begin{array}{l}\text { Saya merasa ragu ketika harus menjelaskan sebuah } \\
\text { solusi dari permasalahan matematika. }\end{array}$ & & & & \\
\hline
\end{tabular}

Gambar 1. Instrumen Non Tes Self Confidence

2. Pak Dadang membeli 1 kuintal berasa dengan harga Rp 11.400 per kg. Kemudian pak dadang menjual beras tersebut dan memperoleh uang sebesar Rp 1.083.000. Setelah ia menjual beras tersebut apakah pak dadang mengalami untung atau rugi? Jelaskan alasannya dan hitunglah presentase untung atau rugi dari hasil penjualan tersebut.

Gambar 2. Instrumen tes hasil belajar matematika

\section{HASIL DAN DISKUSI}

Berdasarkan hasil perhitungan menurut kriteria pengelompokkan yang ditentukan, diperoleh hasil pengelompokkan self-confidence (kepercayaan diri) peserta didik sebagai berikut:

Tabel 2. Tingkat Self Confidence Peserta Didik

\begin{tabular}{|l|c|c|}
\hline Tingkat Self Confidence & $\begin{array}{c}\text { Jumlah } \\
\text { Peserta Didik }\end{array}$ & Persentase \\
\hline Tinggi & 5 & $16.13 \%$ \\
\hline Sedang & 21 & $67.74 \%$ \\
\hline Rendah & 5 & $16.13 \%$ \\
\hline Jumlah & $\mathbf{3 1}$ & $\mathbf{1 0 0 \%}$ \\
\hline
\end{tabular}

Setelah melaksanakan tes berbentuk uraian sesuai dengan indikator hasil belajar, hasil analisis perolehan hasil belajar matematika peserta didik ditinjau dari self-confidence adalah sebagai berikut:

Tabel 3. Persentase rata-rata hasil belajar matematika peserta didik ditinjau dari self-confidence.

\begin{tabular}{|l|c|c|c|c|c|c|}
\hline \multirow{2}{*}{$\begin{array}{c}\text { Tingkat } \\
\text { Self Confidence }\end{array}$} & $\mathbf{1}$ & $\mathbf{2}$ & $\mathbf{3}$ & $\mathbf{4}$ & $\mathbf{5}$ & Rata-rata \\
\cline { 2 - 7 } & $95 \%$ & $93 \%$ & $80 \%$ & $75 \%$ & $50 \%$ & $78.60 \%$ \\
\hline Tinggi & $90.48 \%$ & $88.81 \%$ & $72.14 \%$ & $67.86 \%$ & $50.14 \%$ & $75.29 \%$ \\
\hline Sedang & $85 \%$ & $78 \%$ & $68 \%$ & $87 \%$ & $20 \%$ & $67.60 \%$ \\
\hline Rendah & $90.16 \%$ & $86.60 \%$ & $73.38 \%$ & $76.62 \%$ & $42.38 \%$ & $73.83 \%$ \\
\hline Rata-rata
\end{tabular}


Data dari tabel 3 merupakan persentase hasil belajar matematika yang diperoleh peserta didik ditinjau dari self-confidence. Berdasarkan tabel 3, peserta didik dengan kategori tingkat self-confidence tinggi, mendapatkan persentase tertinggi pada 4 soal dari 5 soal yang ada. Hal tersebut dapat diartikan jika peserta didik memiliki pengetahuan dan pemahaman cukup baik terhadap materi yang sudah dipelajari. Peserta didik dengan tingkat ini memiliki persentase sedikit lebih rendah jika dibandingkan dengan peserta didik dengan kategori tingkat self-confidence sedang dan rendah pada soal nomor 4 dan nomor 5 pada indikator pemahaman. Rata-rata pencapaian hasil belajar yang didapat oleh peserta didik pada kategori ini sebesar $78.60 \%$.

Peserta didik dengan kategori tingkat self-confidence sedang, pada soal nomor 5 mendapatkan persentase tertinggi dengan indikator pemahaman meskipun persentase yang didapatkan tidak terlihat perbedaan yang signifikan dengan peserta didik dengan kategori tingkat self-confidence tinggi. Sedangkan pada soal nomor 4 peserta didik mendapatkan persentase paling rendah dengan indikator yang sama seperti soal nomor 5. Artinya pada indikator tersebut peserta didik tidak sepenuhnya menguasai jika dihadapkan dengan berbagai macam bentuk masalah. Untuk soal nomor 5 persentase yang didapat tidak menunjukkan perbedaan yang signifikan dengan peserta didik tingkat self-confidence tinggi. Rata-rata pencapaian hasil belajar yang didapat oleh peserta didik pada kategori ini sebesar $75.29 \%$.

Untuk peserta didik dengan kategori tingkat self-confidence rendah mendapatkan persentase tertinggi pada soal nomor 4. Artinya siswa memiliki penguasaan yang cukup baik dalam memahami atau mengetahui suatu permasalahan. Sejalan dengan Nuriati et al., (2021) bahwa memahami merupakan kemampuan seseorang dalam mengetahui sesuatu. Sedangkan perolehan persentase terendah terdapat pada soal nomor 5 jika dibandingkan dengan 4 nomor soal lainnya, dimana soal nomor 5 ialah soal yang memang sedikit lebih sulit yang membutuhkan pemahaman lebih dalam memahami makna yang ada pada soal. Ratarata pencapaian hasil belajar yang didapat oleh peserta didik pada kategori ini sebesar $67.60 \%$.

Indikator hasil belajar yang mendapatkan persentase tertinggi terdapat pada soal nomor 1 dengan indikator pengetahuan. Sedangkan persentase terendah terdapat pada soal nomor 5 dengan indikator pemahaman yang melibatkan kemampuan berpikir, menjelaskan, dan menyimpulkan. Meskipun dalam soal nomor 4 dan nomor 5 memuat indikator yang sama, namun mendapatkan persentase hasil belajar yang berbeda. Ini artinya bahwa peserta didik tidak sepenuhnya menguasai materi sehingga kurang bisa memecahkan masalah yang memuat indikator yang sama dalam berbagai kondisi masalah.

Berikut adalah analisis hasil belajar matematika peserta didik berdasarkan tingkat self-confidence dengan melihat pada hasil jawaban peserta didik:

\section{Self Confidence Tinggi}

\section{Indikator Hasil Belajar: Pengetahuan (Soal Nomor 1)}

Berdasarkan hasil jawaban peserta didik, indikator pengetahuan dapat dicapai oleh peserta didik S26. Peserta didik S26 dapat memahami makna soal dengan baik, mengenal dan mengingat kembali suatu masalah. Terlihat dari cara penyelesaian yang digunakan S26 sudah tepat, subjek juga mengetahui hasil akhir yang ditanyakan pada soal. Sedangkan siswa S18 belum mampu mencapai indikator tersebut. Peserta 
didik S18 dapat mengerjakan soal dengan menggunakan cara atau rumus yang benar tetapi hasil akhir yang ditanyakan soal tidak benar, kesalahan terjadi pada saat mencari persentase rugi, seharusnya besar rugi dibagi dengan besar modal yang dikeluarkan untuk membeli dan memperbaiki sepeda. Artinya terlihat bahwa peserta didik S18 belum mampu mengenal atau mengingat kembali suatu masalah yang diberikan, padahal soal tersebut merupakan soal rutin persis dengan soal-soal yang sudah dijelaskan.

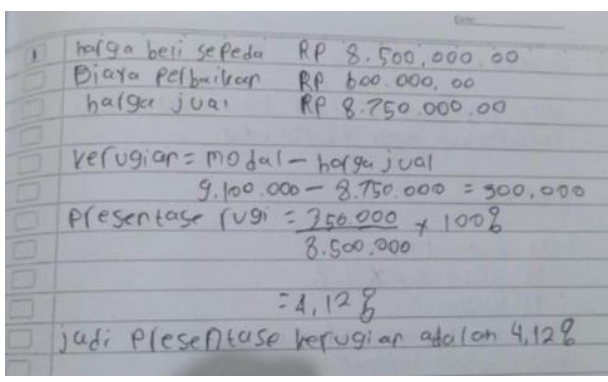

Gambar 3. Jawaban S18

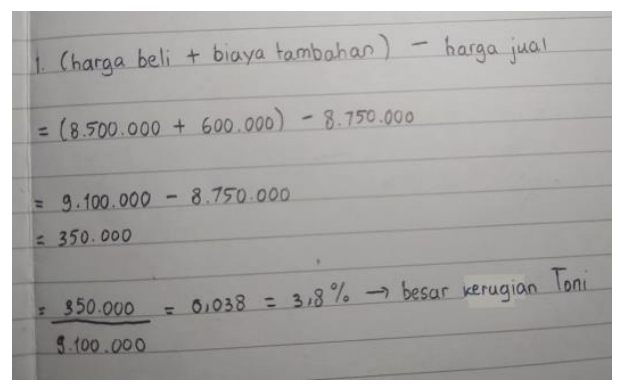

Gambar 4. Jawaban S26

\section{Self Confidence Sedang}

Indikator Hasil Belajar: Aplikasi (Soal Nomor 3)

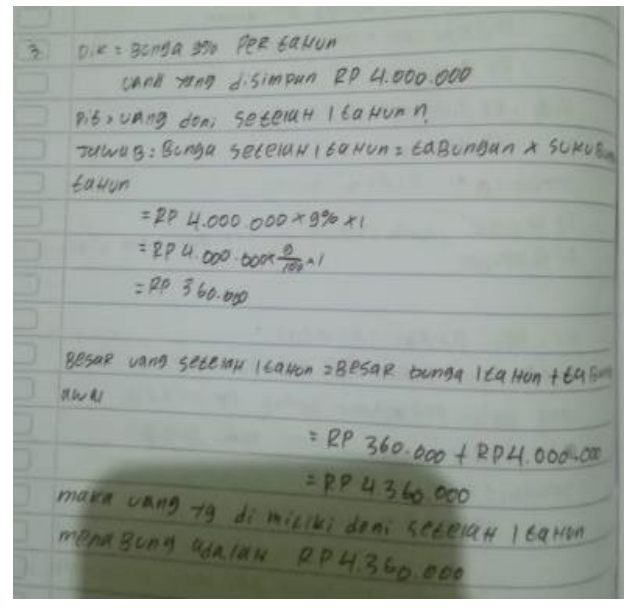

Gambar 5. Jawaban S9

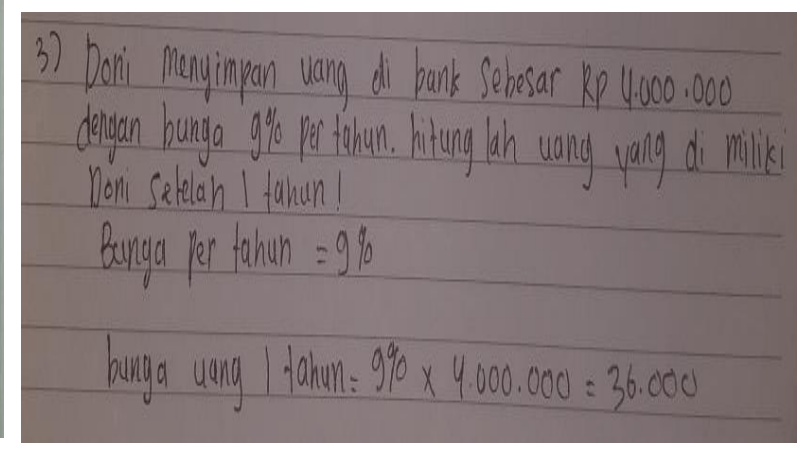

Gambar 6. Jawaban S11

Berdasarkan hasil jawaban peserta didik, indikator aplikasi atau penerapan dapat dicapai oleh peserta didik S9. Peserta didik menyelesaikan soal dengan baik, dapat menerapkan konsep atau rumus yang sesuai dengan apa yang diketahui dan ditanyakan pada soal nomor 3. Sedangkan peserta didik S11 belum mampu mencapai indikator ini. Peserta didik S11 mengerjakan soal tanpa menerapkan konsep atau rumus yang sesuai dengan soal nomor 3, selain itu hasil akhir yang ditanyakan pada soal tidak benar. Terlihat jawaban peserta didik didapatkan hasil yang hanya asal menjawab tanpa menuliskan bagaimana langkah penyelesaian dalam menjawab soal. Artinya peserta didik tidak mencapai indikator penerapan karena tidak dapat memilih cara atau konsep untuk menghitung dan menyelesaikan soal sesuai dengan apa yang ditanyakan, sehingga hasil yang diperoleh tidak benar. 


\section{Self Confidence Rendah}

Indikator hasil belajar: pemahaman (Soal Nomor 4)

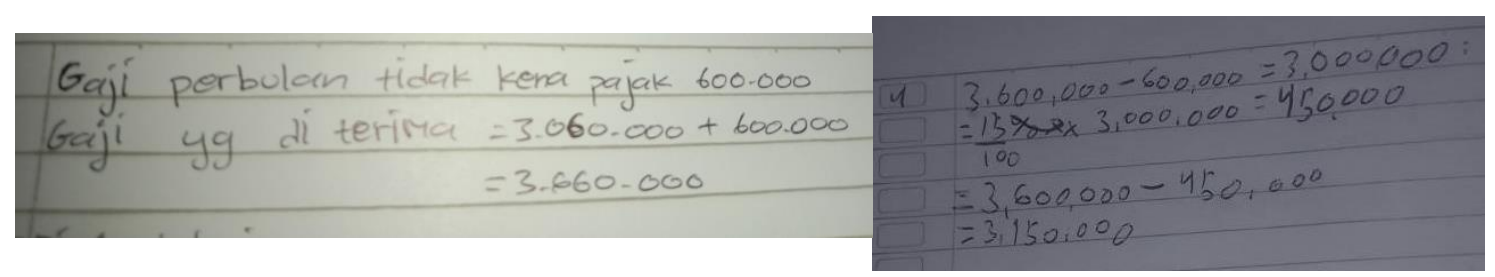

Gambar 7. Jawaban S1

Gambar 8. Jawaban S30

Berdasarkan hasil jawaban peserta didik, indikator pemahaman dapat dicapai oleh peserta didik S30. Peserta didik S30 mampu memahami soal dengan baik dengan cara penyelesaian yang tepat dan terlihat hasil akhir yang ditanyakan pada soal benar. Sedangkan siswa S1 belum mampu mencapai indikator ini, peserta didik S1 belum mampu memahami dan mengerti makna soal dengan baik. Terlihat jawaban peserta didik didapatkan hasil yang hanya asal menjawab tanpa memahami apa yang diketahui dan ditanyakan pada soal. Artinya peserta didik S1 belum mampu memecahkan masalah yang diberikan sehingga tidak dapat mencapai indikator tersebut.

Faktor-faktor yang dapat mempengaruhi pencapaian hasil belajar matematika peserta didik selain aspek afektif, tentu terdapat faktor-faktor lain yang mempengaruhi. Hal tersebut digali oleh penulis dengan melakukan wawancara pada peserta didik berdasarkan tingkat self-confidence. Peserta didik dengan kategori tingkat self-confidence tinggi berpendapat bahwa soal tidak sulit dan mudah dipahami, peserta didik sudah paham akan soal yang diberikan dan bagaimana cara penyelesaiannya. Selain itu, peserta didik sering mempelajari kembali secara mandiri terkait materi yang sudah dijelaskan oleh guru, sehingga mereka lebih memahami masalah yang diberikan. Namun terkadang peserta didik kurang teliti saat menyelesaikan soal sehingga banyak terjadi kesalahan dalam perhitungan dan tidak ada kesulitan yang berarti.

Peserta didik dengan kategori tingkat self-confidence sedang berpendapat bahwa soal tidak sulit. Seringnya peserta didik mengalami hambatan saat mengerjakan soal karena kurang memahami soal yang telah dimodifikasi, merasa baru menemukan soal yang seperti itu sehingga peserta didik memerlukan waktu yang lebih lama dalam memahami makna soal yang diberikan, serta mencari solusi atau penyelesaiannya dari apa yang ditanyakan pada soal. Selain itu peserta didik cenderung tidak mempelajari kembali secara mandiri terkait materi yang sudah dijelaskan oleh guru, sehingga mereka kurang menguasai suatu konsep materi.

Peserta didik dengan kategori tingkat self-confidence rendah berpendapat bahwa peserta didik mengalami kesulitan pada soal nomor 5. Peserta didik lebih mudah menyerah saat bertemu dengan soalsoal yang sulit dan akan cenderung diabaikan, karena peserta didik tidak mempelajari kembali secara mandiri terkait materi yang sudah dijelaskan oleh guru. Hal tersebut dapat terjadi akibat kurang terdorongnya rasa ingin tahu peserta didik (Trisnawati et al., 2018), sehingga mereka tidak memahami suatu konsep materi dan tidak terbiasa dengan soal-soal yang dimodifikasi. Selain itu peserta didik pada kategori ini lebih mudah merasa tidak percaya diri terhadap kemampuannya, merasa bahwa ia tidak mampu dalam 
menyelesaikan permasalahan yang diberikan. Dimana rasa kepercayaan diri itulah peserta didik dapat lebih mempercayai kemampuannya sendiri (Nilasari et al., 2020), sehingga hal tersebut mengakibatkan tidak ada semangat serta motivasi peserta didik untuk mencoba mencari solusi penyelesaian. Dalam penelitiannya, Purnama \& Mertika (2018) menemukan bahwa seseorang dengan kepercayaan diri rendah, akan membuat seseorang tersebut mengalami kelambatan dalam pembelajaran matematika, sehingga peserta didik dengan kepercayaan diri yang baik, akan mampu menyelesaikan tugas-tugasnya (Nurul et al., 2019).

\section{KESIMPULAN}

Berdasarkan hasil penelitian dan pembahasan, dapat disimpulkan bahwa terdapat hubungan antara self-confidence dengan hasil belajar matematika. Sesuai persentase pencapaian hasil belajar matematika berdasarkan tingkat self-confidence, peserta didik dengan kategori tingkat self-confidence tinggi akan memperoleh hasil belajar matematika yang juga tinggi, meskipun persentase pada tingkat self-confidence tinggi dan sedang tidak terlihat perbedaan yang signifikan dan persentase pada tiap soal berdasarkan indikator hasil belajar juga memperoleh hasil yang sangat beragam. Perolehan persentase pencapaian tertinggi pada peserta didik dengan kategori tingkat self-confidence tinggi terdapat pada 3 dari 5 soal. Untuk peserta didik dengan kategori tingkat self-confidence sedang memperoleh pencapaian tertinggi yaitu pada soal nomor 5 tetapi rendah dalam soal nomor 4, padahal indikator pada soal nomor 4 dan 5 sama yaitu pemahaman. Artinya peserta didik hanya dapat mencapai dan menguasai indikator ini dalam bentuk permasalahan tertentu. Sedangkan peserta didik dengan kategori tingkat self-confidence rendah memperoleh pencapaian tertinggi pada soal nomor 4 dan rendah pada soal nomor 5 dengan indikator yang sama. Secara keseluruhan, pencapaian hasil belajar matematika peserta didik mendapatkan persentase sebesar 73,83\%. Selain itu, faktor atau penyebab lain yang mempengaruhi hasil belajar matematika peserta didik yaitu adanya kesalahan dalam proses perhitungan akibat kurangnya ketelitian peserta didik pada saat menyelesaikan soal, kurang memahami soal dan konsep materi pembelajaran karena tidak mengulang kembali materi secara mandiri, peserta didik mudah putus asa jika bertemu dengan soal yang sukar atau berbeda dari yang rutin diberikan, dan salah dalam menentukan metode atau cara penyelesaian.

\section{REFERENSI}

Ferdianto, F., \& Yesino, L. (2019). Analisis Kesalahan Siswa dalam Menyelesaikan Soal Pada Materi SPLDV Ditinjau dari Indikator Kemampuan Matematis. SJME (Supremum Journal of Mathematics Education), 3(1), 32-36. https://doi.org/10.31235/osf.io/kmwg6

Hildingsson, I., Lindgren, H., Karlström, A., Christensson, K., Bäck, L., Mudokwenyu-Rawdon, C., Maimbolwa, M. C., Laisser, R. M., Omoni, G., Chimwaza, A., Mwebaza, E., Kiruja, J., \& Sharma, B. (2019). African midwifery students' self-assessed confidence in antenatal care: a multi-country study. Global Health Action, 12(1). https://doi.org/10.1080/16549716.2019.1689721

Masruroh, A. A., Faturohman, Y., Hidayat, W., \& Rohaeti, E. E. (2019). Analisis Self Confidence Siswa 
Kelas X Ht 3 Smk Sangkuriang 2 Dalam Pembelajaran Matematika. JPMI (Jurnal Pembelajaran Matematika Inovatif), 2(6), 379-384. https://doi.org/10.22460/jpmi.v2i6.p379-384

Nilasari, A., Effendi, M. M., \& Putri, O. R. U. (2020). Analisis Self-Confidence Dan Hasil Belajar Matematika Sma Dalam Kurikulum Berbasis Unit Kegiatan Belajar Mandiri. AKSIOMA: Jurnal Program Studi Pendidikan Matematika, 9(2), 433-439. https://doi.org/10.24127/ajpm.v9i2.2800

Novtiar, C., \& Aripin, U. (2017). Meningkatkan Kemampuan Berpikir Kritis Matematis Dan Kepercayaan Diri Siswa Smp Melalui Pendekatan Open Ended. Jurnal PRISMA Universitas Suryakancana, 6(2), 119-131. https://doi.org/10.35194/jp.v6i2.122

Nuraeni, Mulyati, E. S., \& Maya, R. (2018). ANALISIS KEMAMPUAN PEMAHAMAN MATEMATIS DAN TINGKAT KEPERCAYAAN DIRI PADA SISWA MTs. JPMI (Jurnal Pembelajaran Matematika Inovatif), 1(5), 975-982. https://doi.org/10.22460/jpmi.v1i5.p975-983

Nuriati, N., Suhar, \& Ndia, L. (2021). Analisis Hasil Belajar Matematika Siswa Kelas VII SMP NEGERI 1 Kabangka Ditinjau Dari Jenis Kelamin. 9(1), 141-154. https://doi.org/10.36709/jppm.v9i1.16758

Nurojab, E. S., \& Sari, V. T. A. (2019). Hubungan Self Confidence Terhadap Kemampuan Pemecahan Masalah Matematik Siswa. JPMI (Jurnal Pembelajaran Matematika Inovatif), 2(5), 329-336.

Nurul, Octaviani A, \& Zanthy L.S. (2019). Analisis Kemampuan Koneksi Matematis Dan Komunikasi Matematis Ditinjau Dari Kepercayaan Diri Siswa SMP. JPMI (Jurnal Pembelajaran Matematika Inovatif), 2(2), 57-64.

Oktaviana, D., \& Prihatin, I. (2018). Analisis Hasil Belajar Siswa Pada Materi Perbandingan Berdasarkan Ranah Kognitif Revisi Taksonomi Bloom. Buana Matematika: Jurnal Ilmiah Matematika Dan Pendidikan Matematika, 8(2), 81-88. https://doi.org/10.36456/buana_matematika.8.2:.1732.81-88

Prof. Dr. Sugiyono. (2016). Metode Penelitian Kualitatif, Kuantitatif, $R \& D$ (23rd ed.). Alfabeta.

Purnama, S., \& Mertika. (2018). Analisis Kemampuan Pemecahan Masalah Siswa Ditinjau dari Self Confidence. Journal of Educational Review and Research, 1(1), 59-63. http://ejurnal.unisda.ac.id/index.php/Inspiramatika/article/view/1252

Ramdan, Z. M., Veralita, L., Rohaeti, E. E., \& Purwasih, R. (2018). ANALISIS SELF CONFIDENCE TERHADAP KEMAMPUAN PEMECAHAN MASALAH MATEMATIS SISWA SMK PADA MATERI BARISAN DAN DERET. AKSIOMA: Jurnal Program Studi Pendidikan Matematika, 7(2), 171-179.

Saihu, S. (2020). The Effect of Using Talking Stick Learning Model on Student Learning Outcomes in Islamic Primary School of Jamiatul Khair, Ciledug Tangerang. Tarbawi: Jurnal Keilmuan Manajemen 
Pendidikan, 6(01), 61. https://doi.org/10.32678/tarbawi.v6i01.2325

Salamah, D. P., \& Amelia, R. (2020). ANALISIS KESALAHAN BERDASARKAN TAHAPAN NEWMAN TERHADAP MATERI PELUANG KEJADIAN MAJEMUK DITINJAU DARI GENDER DAN SELF CONFIDENCE PADA SISWA KELAS XII SMK DI BANDUNG BARAT. 3(4), 273-284. https://doi.org/10.22460/jpmi.v3i4.273-284

Sari, N. R., Hidayat, W., \& Yuliani, A. (2019). Analisis Hasil Belajar Matematika Siswa Kelas X SMA Pada Materi SPLTV Ditinjau Dari Self-Efficacy. UNION: Jurnal Ilmiah Pendidikan Matematikafile:///C:/Users/Saviraa Jellek/Downloads/124-Article Text-539-4-10-20191130.Pdf, 7(1), 93-103. https://doi.org/10.30738/union.v7i1.3776

Trisnawati, I., Pratiwi, W., Nurfauziah, P., \& Maya, R. (2018). Analisis Kemampuan Berpikir Kreatif Matematis Siswa Sma Kelas Xi Pada Materi Trigonometri Di Tinjau Dari Self Confidence. JPMI (Jurnal Pembelajaran Matematika Inovatif), 1(3), 383-394. https://doi.org/10.22460/jpmi.v1i3.p383394

Ulfa, D., Rahmi, D., \& Revita, R. (2019). PENGARUH PENERAPAN MODEL PEMBELAJARAN CORE TERHADAP KEMAMPUAN PEMECAHAN MASALAH MATEMATIS BERDASARKAN SELFCONFIDENCE SISWA SMP / MTS. Journal Cendekia, 03(02), 400-409.

Yukentin, Y., Munawaroh, M., \& Winarso, W. (2018). Analisis Hasil Belajar Matematika Siswa Ditinjau Dari Perbedaan Kepribadian Ekstrovert Dan Introvert. JIPMat, 3(2), 163-168. https://doi.org/10.26877/jipmat.v3i2.2700. 